\title{
Desmopressine helpt niet bij nycturie
}

Ilse Hofmeester, Marco Blanker

Eén keer per nacht of vaker ontwaken om te plassen (nycturie) komt veel voor. Nycturie neemt toe met de leeftijd, leidt tot minder slaap en een lagere kwaliteit van leven. Desmopressine zou nycturie tegengaan, maar de auteurs van een recente Cochrane-review vonden daarvoor geen bewijs.

Desmopressine is een antidiuretisch hormoon dat de urineproductie in de nacht verlaagt bij innemen voor het slapengaan. Het middel wordt al langer ingezet bij nachtelijke enuresis en centrale diabetes insipidus, maar wordt sinds kort ook toegepast bij de behandeling van nycturie. De belangrijkste bijwerkingen van desmopressine zijn hoofdpijn, hyponatriëmie, insomnia, droge mond, hypertensie, buikpijn, perifeer oedeem en misselijkheid. Bij een enkeling kan hyponatriëmie tot zeer ernstige problemen leiden.

Ham et al. onderzochten de effecten van desmopressine op nycturie bij mannen. ${ }^{1}$ De auteurs includeerden 14 onderzoeken, waarin 2966 mannen gerandomiseerd werden behandeld. Zij beschrijven vijf verschillende vergelijkingen.

Voor resultaten op korte termijn ( $<3$ maanden) blijkt er sprake van een lage kwaliteit van bewijs. Op middellange termijn (tot 12 maanden) lijkt desmopressine het aantal nachtelijke plassen sterker te verminderen dan placebo: een verschil van 0,46 plassen per nacht. Het effect is vergelijkbaar met alfablokkers, zonder duidelijke bijwerkingen. Toevoegen van desmopressine aan een alfablokker lijkt geen toegevoegde waarde te hebben. De beperkingen van deze review zijn de korte follow-upduur, methodologische beperkingen en onnauwkeurigheid van de onderzoeken. De auteurs benadrukken dat het gevonden effect weliswaar statistisch significant is, maar niet klinisch relevant.

\section{ONDUIDELIJK EFFECT}

De kwaliteit van de geïncludeerde onderzoeken is zeer laag tot redelijk. Alle onderzoeken in de review zijn uitgevoerd in de tweede lijn. De auteurs konden slechts een klein aantal van de tevoren geplande analyses uitvoeren door het ontbreken van data. De review is wel goed opgezet, inclusief de beschrijving van de financieringsbronnen van de afzonderlijke onderzoeken. Zeker bij de analyse van de werkzaamheid van medicatie is het relevant om na te gaan of het vooral onderzoeken betreft die werden gesponsord door de farmaceut. In zes van de veertien onderzoeken werd sponsoring vermeld. Daarbij bestaat een reëel risico op selectieve rapportage van positieve uitkomsten (publicatiebias), waardoor een te rooskleurig beeld van het effect van desmopressine ontstaat. In dat licht is het goed te noemen dat er in twee onderzoeken actieve 'run-in'-perioden met desmopressine werden gebruikt. In een van deze onderzoeken werden patiënten die tijdens de 'run-in'-periode niet reageerden op desmopressine uitgesloten van het verdere on-

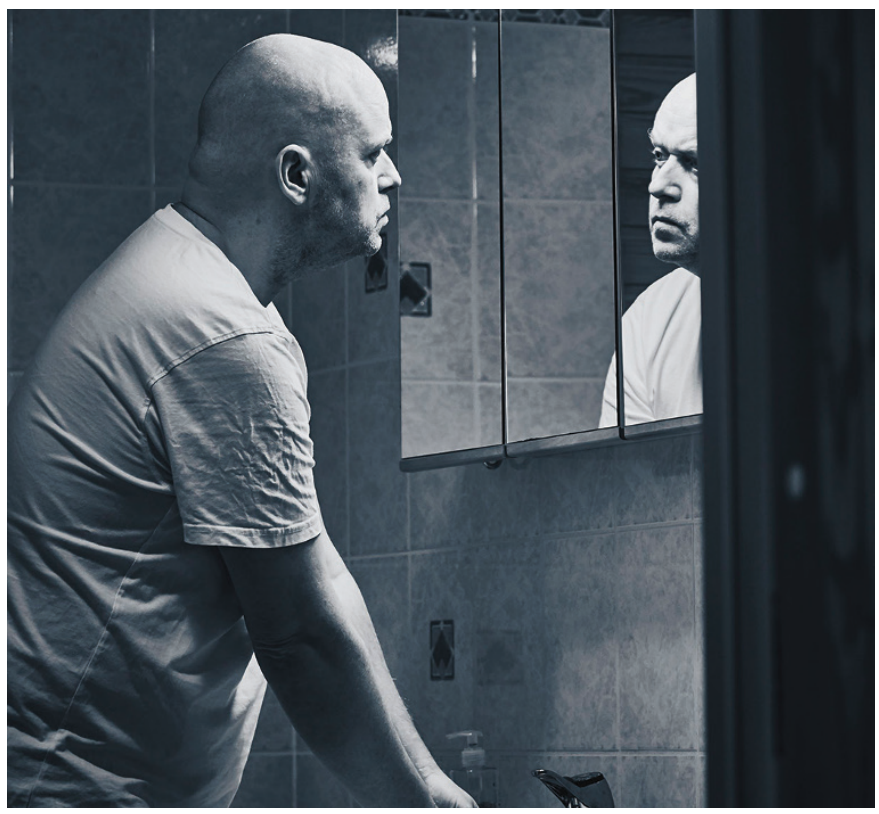

Nycturie leidt tot minder slaap en een lagere kwaliteit van leven.

derzoek, wat leidt tot een overschatting van het mogelijke effect. Bij correctie hiervoor bleek het verschil tussen desmopressine en placebo nog kleiner: 0,35 plassen per nacht.

Daarnaast poogden de auteurs tevergeefs om aanvullende informatie van fabrikanten en sponsors te krijgen. Zij merken dan ook terecht op dat dit vragen oproept over het bestaan van publicatiebias. Ook selectie- en informatiebias waren in de meeste onderzoeken aanwezig, waardoor we de conclusies van de review niet direct als de waarheid kunnen aannemen. Uit de subgroepanalyses blijkt dat er een groter effect van desmopressine optreedt bij een hogere dosis en bij nachtelijke polyurie. De meeste patiënten met nycturie hebben echter nachtelijke polyurie. Dit komt onder andere doordat de eerste ochtendurine wordt meegeteld bij de's nachts geproduceerde urine. Andersom betekent dit dat veel mensen met nachtelijke polyurie niet per se's nachts plassen. Ten slotte blijkt ook hier het effect op het aantal nachtelijke plassen niet klinisch relevant. De uitkomsten van deze review zijn geen aanleiding om het advies over de toepassing van desmopressine in de NHG-Standaard Mictieklachten bij mannen aan te passen. -

\section{LITERATUUR}

1. Han J, Jung JH, Bakker CJ, Ebell MH, Dahm P. Desmopressin for treating nocturia in men. Cochrane Database Syst Rev 2017;10:CD012059.

Hofmeester I, Blanker M. Desmopressine helpt niet bij nycturie. Huisarts Wet 2018;61[8]:40. DOI: 10.1007/s12445-018-0215-z.

Isala, Zwolle, afdeling Urologie: dr. I. Hofmeester, epidemioloog/aios urologie, i.hofmeester@isala.nl. UMCG Groningen, afdeling Huisartsgeneeskunde: dr. M. Blanker, huisarts-epidemioloog.

Mogelijke belangenverstrengeling: niets aangegeven.

Dit is een PEARLS, bruikbare wetenschap voor de werkvloer op basis van de Cochrane Database of Systematic Reviews. 